\title{
THE PRACTICE OF SUSTAINABILITY IN RESPONSE TO THE CHALLENGES OF AGRICULTURE IN MEXICO
}

\author{
A. CALLEROS-ISLAS \\ Institut universitari de recerca en Ciència i Tecnologies de la Sostenibilitat - UNESCO Chair in Sustainability, \\ Universitat Politècnica de Catalunya, Espanya.
}

\begin{abstract}
In Mexico, as in most food producing countries, a complex problem is found in the convergence of a need for a change in the current agro-industrial model for economic, social and environmental reasons and growing food demand. While the existence of strong economic barriers that question the continuity of conventional agribusiness is recognized, it is observed that alternatives such as organic farming have emerged within the same productive and commercial model. Although a sustainability approach broadens the scope of analysis the question is if it consolidates better agricultural practices while supporting decision-making processes and achieving yield goals. Settling previous research results, this paper aims to answer this question through the transposition of theoretical aspects of a case study: a project currently being held in Jalisco, Mexico to promote organic agriculture among maize producers. The exercise provided useful information on results and drawbacks to be expected when applying sustainable principles in the field. It was possible to implement practical actions appropriate to the socio-environmental context that matched economic goals of local farmers, improved soil quality and decreased environmental impacts and external dependence of rural Mexican communities. Nevertheless, the lack of trust between farmers and public institutions, skepticism towards change, the prevalence of immediacy and uncertainty of resource allocation make it hard to achieve any progress questioning whether results can be maintained long-term to facilitate the transition of agroecosystems towards a more sustainable future.
\end{abstract}

Keywords: agroecosystems, local development, organic agriculture, policy-making, sustainability.

\section{INTRODUCTION}

Described as the ability to meet present needs without compromising the ones of the future [1], sustainability has become an important pillar when facing development issues. Therefore, searching for means to help the integration of sustainability into the processes that can lead to real-world actions seems coherent. By this means, sustainable principles can become a common base to keep empowering actions towards more consistent decisions, policies and a more balanced development.

However, while its level of inclusion in discourse and theory is quite broad, sustainability as a discipline still needs to reinforce its operational side. There is a lack of consensus on the definition and practice of sustainability, which shows contradictions between its conceptual and normative conception. The latter refers to the interdisciplinary and diverse conceptualization of sustainability in contrast to its more reductionist predictive statistical practice [2].

The above has a dual effect: in one hand it gives a broader spectrum of sustainability to be applied in different fields and with a transdisciplinary scope [3, 4]; in the other, makes it harder to get solid results and therefore to be considered a scientific approach $[5,6]$. This is strongly related to the challenge of consolidating knowledge at the same time that decision-making processes are enabled [2]. Here is considered that contrasting the principles of sustainability with a case study is relevant to observe the consistency (or the lack of) between sustainability theory and practice.

In Mexico, as in most food producing countries, a complex problem is found in the need to change cropping practices for economic and social reasons and the consequent need for 
proposals to address the shortcomings of the current agro-industrial model [7]. In this regard, on one hand the existence of strong economic barriers that question the continuity of the conventional agribusiness is recognized; and on the other, it is observed that alternatives such as organic farming have also emerged within the same productive and commercial model. Either way, the underlying problem is not being addressed. What is here required is a paradigm shift in agricultural production and marketing to one that allows a more equitable distribution of economic resources and a more sustainable use of natural ones.

The latter is embedded in a context that lacks the appropriate measures to boost local development in Mexico. Extra efforts to compel the creation of public spaces and policies are required. Then, through successful local experiences, dynamics can be generated to allocate resources to develop alternatives within a more holistic scope. This will in turn benefit both the environment and the social fabric at local and regional level [7-9].

The adoption of the principles of sustainability, agroecology and the common-good in the food production and marketing processes is what will set the tone for a new agribusiness model with the well-being of the majority as a priority rather than the economic benefit of the minority.

\subsection{Aim and structure}

This article focuses on analyzing the practical implementation of sustainability principles in promoting a transition towards a local organic agriculture to answer the challenges of agriculture in the Mexican context. After the introduction, the second unit focuses on describing the problem; a third unit shows the methodology implemented in the project; the fourth unit is dedicated to the achieved and expected results, and a final one deals with conclusions.

\section{AGRICULTURE CONTEXT AND CHALLENGES}

Drastic land use changes have occurred in the past 40 years in grain producing countries such as Mexico, and have come with severe consequences being deforestation and land degradation for manure and grains of the most important [10, 11]. Even though every single modification of the natural environment means losing its original characteristics, it has been the adoption of a monoculture agribusiness model what has caused the rapid devastation of agroecosystems in the country (Photograph 1). This has caused a deep impact in society (rising poverty, concentration of resources and the means of production, rural exodus, etc.) and in the environment (soil degradation, water source pollution, biodiversity losses, increased vulnerability of ecosystems, etc.).

The so-called "green revolution" of the 70s - though its roots can be traced back to $1943-$ was carried with the aim of increasing field production through the search of high yielding varieties (HYV) and intensive agriculture [12].

However, as pointed out by different researchers, it has resulted in effects such as the loss of genetic biodiversity, soil impoverishment, increased agrochemical pollution, health issues among the rural population on the rise, among others [10]. Paradoxically the productivity of this whole system is questioned when considering its high dependence on external technologies, the cost of inputs and its negative effects on human health and the environment $[8,9,13]$.

Due to the implementation of this massive food production system agroindustry is now consolidated worldwide prioritizing markets, technologies and knowledge at global scale over local ones. 


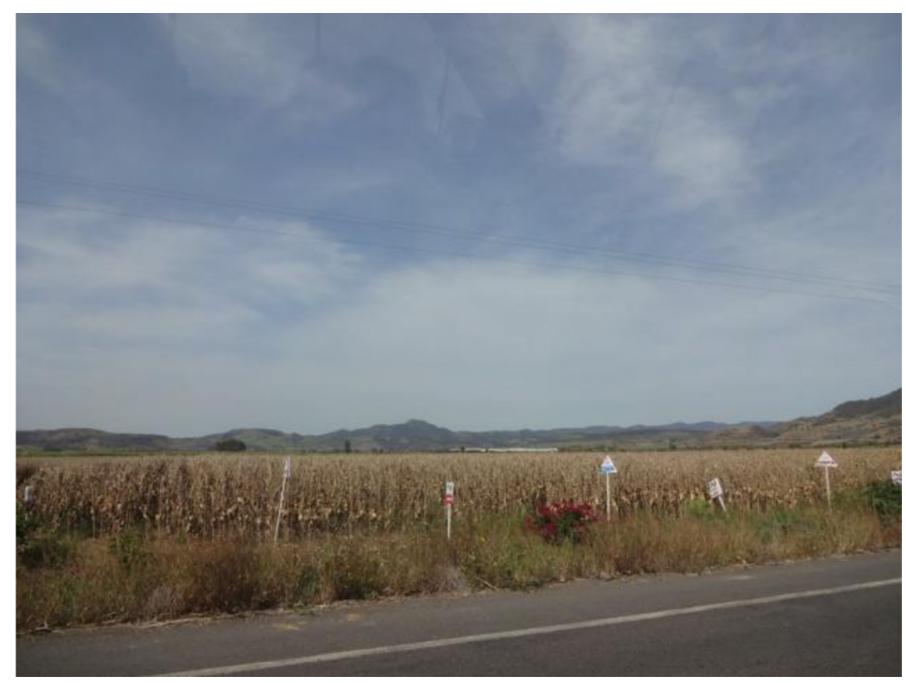

Photograph 1: Maize monoculture Jalisco, Mexico. Every sign shows chemical inputs and/ or modified seeds used in the field. Prepared by the author.

\subsection{Maize}

In the world, the production of maize has been increased by more than $100 \%$ over the last 20 years. In 20131.018 million tons were produced globally, more than doubling the 467 million tons produced in 1993. It is the third most produced crop in the world, and 50\% of it is produced in the American Continent [14].

Maize gains even more importance in Mexico, where it is the most important crop both in volume as in planted area [15]. Regarding maize, Mexico is fourth in production, fifth in seed production and second in imports with more than 10 million tons per year, placing the country as one of the main consumers of this grain [16]. It is worth mentioning that Mexico is self-sufficient in white maize destined mainly for human consumption, but highly deficient in yellow maize destined for industrial uses and feeding cattle, importing $90 \%$ of its final consumption [15].

Maize is the basic grain of the national diet and a cornerstone in the cultural identity of the Mexican people in general and of indigenous people in particular [7, 13, 17]. Mexico counts with 64 different varieties of maize, it is recognized as the country with more genetic diversity and therefore, as the cradle of this grain [18, 19].

Taking this into account is quite clear that consequences of implementing monoculture production of maize are most evident in Mexico, where biological diversity and intangible heritage are to be maintained. Hence, incorporating more sustainable practices in agriculture by adapting methods to the local context, recovering traditional practices and developing techniques according to the social and natural environment is suitable and much needed.

The latter is more relevant considering the great difficulties of making compatible the feeding needs of a growing population with the urgency of mitigating impacts to the environment, where the adapting capacity must be strengthened within a context of socioeconomic crisis and climate change $[9,10,20-23]$. 


\subsection{Organic farming}

Defined as a production system based on maximizing the use of natural resources that are present in crop lands, organic agriculture goes beyond prohibiting agrochemicals. It seeks to maintain (and even enhance) fertility and biological activities of the soil without using synthetic inputs and, whilst minimizing the use of non-renewable resources. All is meant to reduce the impact of agricultural activities on both the natural environment and human health [24].

Agricultural organic land has been constantly rising worldwide for several decades going from 11 million hectares in 1999 to 43,1 in 2013. The organic food market has also grown, especially since 2002 and unlike the rest of the food market, has continued to grow regardless the global economic downturn [25].

While consumption and market of organic products is largely concentrated in the countries of the global north (mainly U.S.A. and E.U.) developing countries concentrate $80 \%$ of all organic producers. Latin America is first in total organic agricultural land with 6,6 million ha. But if considered as the share of total agricultural land, this changes. For example, Argentina is number one in the area with 3.2 Mha and Mexico ranks sixth with only $0.5 \mathrm{Mha}$. As a share of total agricultural land Argentina goes to the ninth place with 2.3\% and Mexico to number seven with the same percentage [26]. As observed, this consideration almost erases the difference between the two countries, but what these data are revealing is how little relevance organic farming still has in Latin American countries.

\subsubsection{The Mexican context}

Mexico has 501.364 ha (2013 data) of organic agricultural land, reaching the $2.27 \%$ of the total agricultural land. After Greece, it is the second country with the highest annual increase reaching a 32.8\% growth from 2011 to 2012 (366.904 ha in 2011). In the 2012-2013 period, this decreased to a $2,9 \%$ corresponding to one of the flash points of the world economic crisis. Mexico is also the country with the largest number of organic producers in Latin America (169.000 in 2013) and third worldwide [25, 26].

The main organic produced crop is coffee, as befits one of the leading countries in producing and exporting organic coffee, representing 35\% of the total organic production. Even so, in relation to other countries, Mexico has a diverse production highlighting avocado, citrus, honey, tropical fruits and vegetables in general [27].

Even so, as in most food producing countries, organic agriculture in Mexico has been oriented to export benefitting large-scale producers. From the total organic production of the country, $85 \%$ is exported, mainly to the United States [27].

The use and production of organic inputs are a viable option for increasing the profitability of crops, especially considering that market prices are higher than those of conventional products. However, this applies only to products certified as organic and this process involves high costs in time and money $[8,9]$. Also to be noted, changing the productive system is not something farmers can do overnight. It is a process of transition that involves many boundaries to overcome.

\subsubsection{The farmer perspective}

One of the biggest challenges for small and medium farmers in Mexico is the rising prices of conventional inputs exacerbated by the financial market situation. Most of them (80\%) being imported goods and with the peso devaluation, conventional inputs are more expensive with 
an increase from $30 \%$ to $50 \%$ [28]. The decreasing effectiveness of these inputs is added creating a loop effect when applied periodically, generating negative effects on human and environmental health. Today, farmers are firsthand watching how the effects of continued use of such inputs are seriously increasing. In addition, commercializing companies operate under a market-oriented logic that often goes against the interests of local producers $[13,17,29]$.

Some common opinions of Mexican maize farmers (with less than 20 ha) include that though organic farming is a trend for the future and only for exported high profitable crops. The current organic certification mechanism is foreign to them. They are also no longer searching for higher yields, but for higher profitability, applying new inputs only if they are well-warranted and/or involve lower costs. They express a need for more economic incentives and subsidies especially because of the market volatility but also because of skepticism towards change. There is also a lack of trust towards public institutions and local farmer organizations because of corruption cases occurred in the near past [30].

Therefore, organic farming must go beyond simply replacing supplies if the target is to involve medium and small farmers. Aspects such as the dependence on the exterior, agriculture based on monocultures, impositions of foreign markets (such as certificates) and other issues as water stress, should be considered. Otherwise, the progress of local agro-ecosystems in terms of sustainability and resilience will be quite limited as seen in Baja California, where organic farms have been increasing, overexploiting aquifers and seriously compromising the water sustainability of the region [31].

This is primarily due to conventional agribusiness itself that for merely economic reasons, have promoted the use of organic inputs under the same standards of transnational corporations $[9,13]$. Even Monsanto (2015) declares in its web page that counts with "conservation agriculture" products and methods, promoting low hazard herbicides that respect the environmental biodiversity.

The latter is embedded in an institutional context that has not been able to fully cover what rural communities truly request. An inclusive approach to address socioeconomic and environmental challenges faced by local producers is still missing [8, 32, 33]. This implies creating spaces for designing public policies that do address the shortcomings of the agribusiness model that still prevails in development plans at national and state level in Mexico, which are permeated by the private interests and neoliberal principles that have guided the government's actions over the last 30 years $[17,34,35]$.

\section{METHODS}

The project "Organic farming promotion and development for grain producers in the state of Jalisco", an object of the present research, focuses on enhancing the transition towards organic production of basic crops to the Mexican diet in Jalisco, Mexico. The work is mainly with groups of maize producers. Being recognized as the place of origin of maize, it is assumed as a well-adapted crop to the climatic and the natural environment of Mexico [18]. In concrete, Jalisco has the orographic characteristics needed to develop diverse cropping activities. Specifically, maize is found in this territory a favorable environment for its development reason why it is the most important crop in the state [12].

The focus is placed in organizations of medium-scale producers (between 5 and 20 ha). This is because these producers have resources of their own and interest because they are personally involved in their crop lands. Medium-scale producers also have an important function on shaking the dynamic of other farmers in the region and since the project has a clear 
interest in reconstructing the social fabric of rural communities, has placed among them its core activities.

As a transition process, the first goal is to reduce production costs. Therefore, even though the price of commercialized products will remain the same, the direct cost-benefit relation will be more favorable to the farmers. Other important benefits will be obtained, such as improving the soil quality, reducing environmental impacts and diminishing dependence with the exterior $[11,18,29]$. These factors will considerably improve the agricultural land conditions that future generations will inherit.

\subsection{Study area}

Jalisco is located in western Mexico (Map 1) and bordered by 7 other states and by the Pacific Ocean to the west. It has an area of 80.137 square kilometers and $68 \%$ of the territory has temperate humid weather with summer rains. The average annual temperature is $20.5^{\circ} \mathrm{C}$ and has $850 \mathrm{~mm}$ average annual total precipitation.

Jalisco is settled in an area where different weathers converge because its territory includes tropical and subtropical regions appropriate of the southern hemisphere as well as temperate and cold regions of the northern hemisphere. Also, three of the four most important mountains of the country come together in Jalisco: Sierra Madre Occidental, Eje Neovolcánico Transversal and Sierra Madre del Sur, in addition to valleys and $351 \mathrm{~km}$ of coastline. This endows great ecological diversity highlighting biodiversity, ranking sixth at national level. Maximum altitude is 4,260 meters and the lowest is at sea level. Several bodies of water are found too accounting for $15 \%$ of Mexico's inland waters, like the Lerma-Santiago River and its tributaries, the Chapala Lake and the Peña Cajon dam [19].

Jalisco is second only to the state of Sinaloa in maize production in the country [36]. However, ranks first in rain-fed crops thanks to precipitation and weather which endows greater sustainability for not depending on expensive irrigation systems or external sources of water.

The project started on July 2014 and was launched aiming to promote directly with farmers a process of transformation from an agrochemical based agriculture to an organic one at local

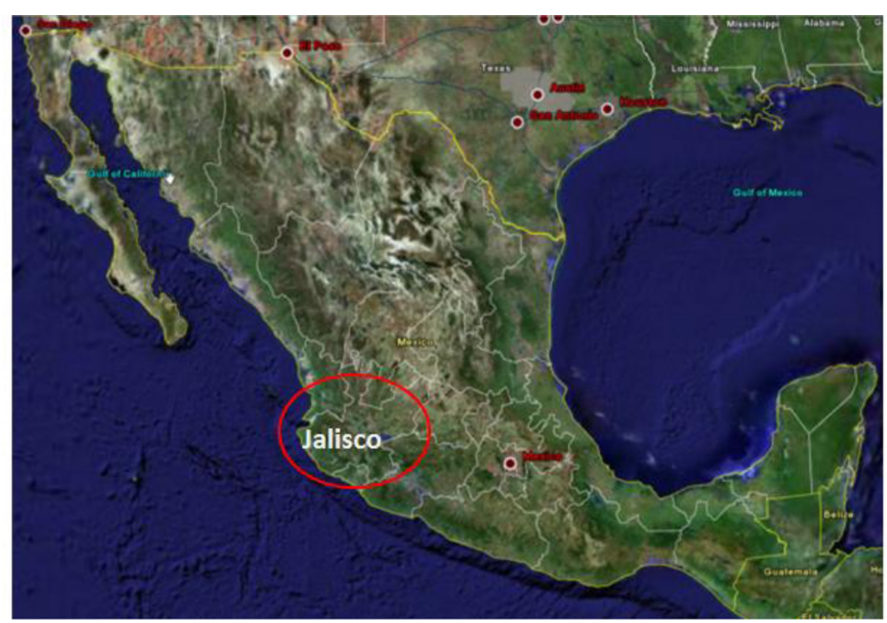

Map 1: Jalisco in Mexico. Adapted from https://www.google.es/maps 


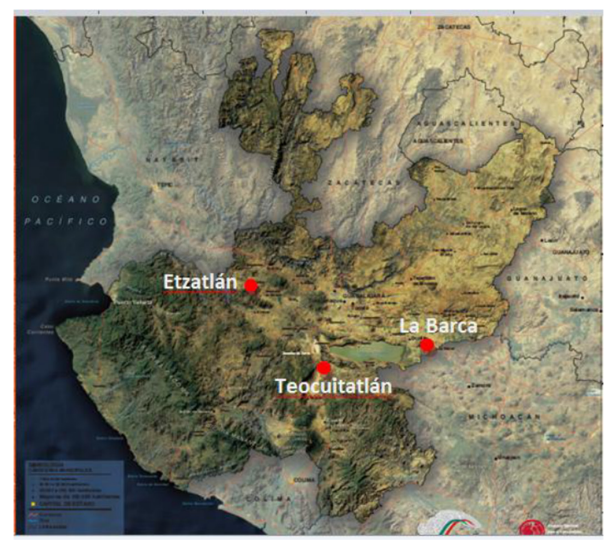

Map 2: Participating organizations in Jalisco. Adapted by the author from CONABIO 2015.

level framed in the principles of agroecology [9, 37]. Participant producers belong to the following organizations (Map 2):

- The Ejido Union Exlaguna de Magdalena in the municipality of Etzatlán.

- The society of rural production (SPR for its Spanish acronym) "Hacienda Los Godinez" in the municipalities of La Barca and Jamay.

- Two groups of the Teocuitatlán de Corona municipality.

\subsection{Diagnosis}

At first, not so favorable comments arise between small and medium farmers when considering organic agriculture as an answer to the problems they face. This is because the closest references lead immediately to elitist markets that impose different requirements involving costly investments and complicated procedures that are beyond the reach of most producers who operate at small and medium scale $[8,9]$.

But today organic farming must be placed far from a fad among elite producers and consumers around the world to be identified as a necessity for the people [30]. The proof is found in producers themselves pointing out the need to change as they directly observe the negative effects of the continued agrochemical application in soil quality and health of the population. Therefore, one of the goals is solving this problem by providing producers with the basic technical elements enabling them to develop their own organic inputs with local resources. This is an important part of the basic principles of agroecology [13, 34]. By doing so, an immediate double effect is generated: in one hand, environmental pollution levels and the exposure of workers to chemicals will considerably decrease; in the other, community resilience is increased and the capacities of the local population are strengthened, decreasing its external dependence $[9,10,18]$.

\subsection{General objective}

Participating groups and the project development consultancy Campo Orgánico Empresarial (Organic Rural Businesses), with the financial support of the Ministry of Rural Development 
of Jalisco (SEDER, Spanish acronym) joined forces to enhance transition towards organic farming.

The proposal was made and entirely driven by Campo Orgánico Empresarial. It was filed to the SEDER searching for financial support because "it is responsible for promoting the agricultural, fishery, aquaculture and agro-industrial development; as well as the integrated and sustainable rural development of the State of Jalisco" [38].

In a broad sense, it is meant to produce food free from synthetic inputs and/or chemicals that can be harmful to the health of the population in general and in particular for direct workers [39]. This would create positive influences for local consumers to easily access a healthier diet. The environment in the region would be favored with reduced agriculture impacts, improved water quality and increased soil microbiota and minerals. The latter is of major importance for the serious problems of soil nitrification and filtration of chemicals to aquifers in the region due to cropping activities $[11,20]$.

\subsection{Specific objectives}

The project is carried out through four strategic lines that shape the action plan (Fig. 1): a participatory diagnosis, advisory sessions, training sessions and a final participatory evaluation. The first two steps have already been done with training sessions currently taking place while participatory evaluation is yet to be done.

Through the participatory diagnosis, firsthand information on the current situation is collected. Capacities and projection of each group are identified as well as the profile of leaders in the group, the opinion of farmers on changing cropping methods, directors-producerstechnicians relationships, productive and technological issues, and existing local expertise in organic farming transition to adapt following activities to each context.

In the advisory sessions, most appropriate alternatives for each group are displayed, using organic ingredients available on the market and produced by national companies. Costs are reduced and production processes become more efficient, but the final goal is that farmers take ownership of their management and application.

Training sessions are meant to make accessible the concept of organic farming for rural population, emphasizing the importance of locally developing human capabilities. Input pro-

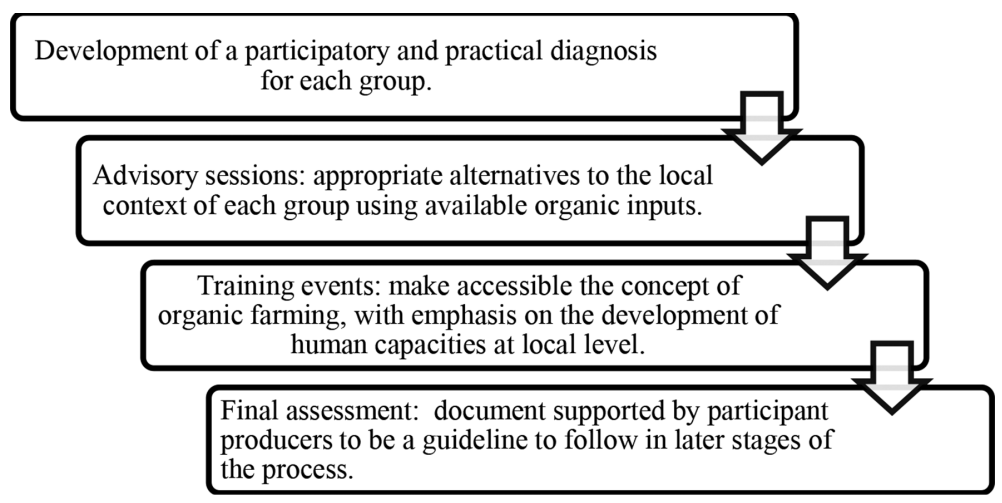

Figure 1: Strategic lines of the Project. Prepared by the author based on documents provided by Campo Orgánico Empresarial. 
duction will begin in these events under the "learning by doing" method, which strengthens social participation and rebuilds social capital.

Final evaluation consists of a document endorsed by participant producers to be a guideline for future stages of the process. The goal is to allow adapting the action plan for dissemination.

\section{RESULTS \& DISCUSSION}

Each producer personally determined the surface allocated to transition towards organic farming. Organic inputs were tested according to the proportions in Table 1.

\subsection{Achieved results}

Actions developed in the area destined to organic farming transition (Fig. 2), regardless the percentage of total area that represents, started with a process of soil recovery. This included fertilizing with humified and mineralized organic matter and reducing by half chemical fertilization. Then, bio-enzymes were applied in the leaves of plants to nourish them and fight some pests, especially in early development stages. Finally, a custom non-chemical control of pests and diseases was established to match the characteristics of each agricultural ecosystem.

After two years, the main results are the reduction of total costs in $20 \%$ and the elimination of half the chemical inputs applied. Of especial importance is the abandonment of broad-spectrum non-selective herbicides and insecticides. The use of urea was substituted with organic inputs in 50\% in comparison with conventional cropping system which is translated into

Table 1: Distribution options of the total crop land between conventional and organic systems.

\begin{tabular}{lcc}
\hline & $\begin{array}{c}\text { Percentage of Has engaged in } \\
\text { conventional farming }(\%)\end{array}$ & $\begin{array}{c}\text { Percentage of Has engaged in organic } \\
\text { farming transition }(\%)\end{array}$ \\
\hline Option 1 & 70 & 30 \\
Option 2 & 60 & 40 \\
Option 3 & 30 & 70 \\
\hline
\end{tabular}

Prepared by the author based on documents provided by Campo Orgánico Empresarial.
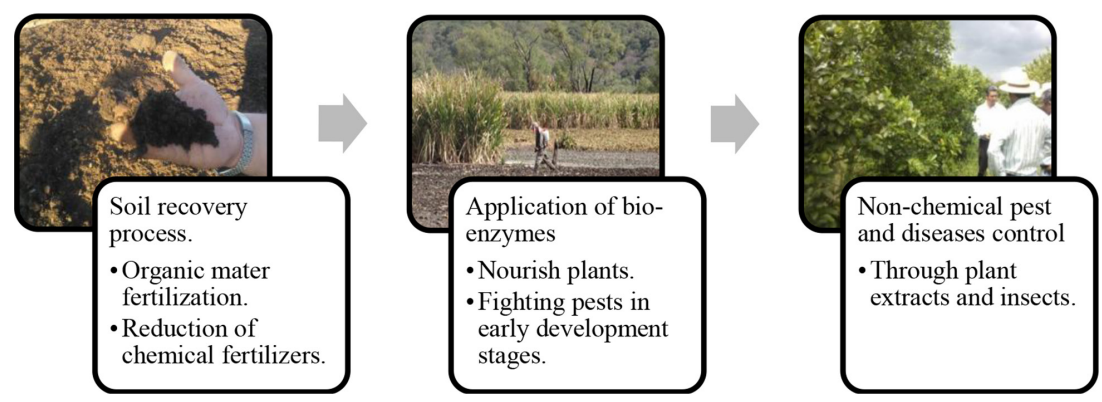

Figure 2: Actions developed in the area destined to organic farming. Prepared by the author based on documents provided by Campo Orgánico Empresarial. 
cutting by half the risk of eutrophication and other impacts such as ammonia and nitrous oxide emissions [16]. Soils have been enriched considerably with organic matter and minerals decreasing compaction, salinity and acidity. These results were observed on-site through simple empirical tests and monitoring. For example, soil compaction was hand measured to check its porosity in each period, before and after incorporating organic matter.

\subsection{Expected results}

Having provided the necessary technical elements to the groups, in the medium term it is intended to build production systems of organic inputs or "bio-factories". These systems enable producers to locally develop the organic inputs needed for each crop using their own natural and economic resources. For implementation, strong advising and training actions of organizations are needed as well as sharing of farmer-to-farmer experiences.

Economic viability may be simply verified considering that installing a bio-factory with 500ha supplying capacity (considering operating expenses and costs in Mexico) profits are obtained in one year. Just chemical fertilization requirements for the same 500ha amount to more than $100.000 €[36]$, and being substituted with organic inputs from the bio-factory it is clear that the project brings significant economic benefits for local producers.

The production of solid and liquid organic fertilizers, green manure from native plants, mineral and manure bio-enzymes, as well as bio-control of pests and diseases, are the main functions of the bio-factories. They also help restore the balance of minerals and organic matter of soils and allow the use of raw materials from crop residues and underused local resources, such as manure, minerals, herbs and/or natural repellents (garlic, onion, chili, etc.) with the consequent reduction of costs $[11,20,29,40]$. In addition, control of production processes is given to local producers creating employment in the communities, increasing their self-sufficiency and their ability to adapt to changes $[9,18]$. Autonomy of rural communities will increase by generating added value in the region.

Actions are expected to be carried out by each group through inclusive practices and participatory processes to upgrade rural areas through strengthening family bonds [30]. This will be achieved through diversifying productive activities at local level and developing rural social enterprises (cooperatives), helping slow down migration and field abandonment processes that favor family disintegration and impoverishment of rural societies in Mexico.

Local production of organic inputs through a gradual process based on the availability of natural and economic resources will be complemented with the remaining $40 \%$ of inputs that cannot be produced locally for their high technical and infrastructure requirements, such as the reproduction of fungi, bacteria and other beneficial organisms.

\subsection{Discussion}

Limited economic resources prevented us from carrying out chemical analysis of soils. This hampered the possibility of monitoring chemical composition and therefore more solid results were not achieved. Instead, empirical tests based on direct observation and unstructured interviews with farmers were made and contrasted throughout the process.

The most important drawback was the mismatch between public administration deadlines and crop stages that rely on seasonal changes, especially when it comes to rainfed crops. This translated into significant delays and hindered the development of the action plan. Also, generated a negative effect on the farmers as highlighted by technical staff from Campo Orgánico 
Empresarial, because uncertainty setbacks their involvement in the project and prevented them from completely leaving the use of chemical inputs. Instead of this, they mixed organic and chemical ones, mainly because they expect more guaranties on the outcomes, and are skeptic towards drastic changes, especially on plague control issues.

However, achieved results imply that if the project carries on with special emphasis on training and caring more for accompanying the producer along the crop stages, success of the project can be expected.

\section{CONCLUSIONS}

Providing profitable alternative for maize farmers is mandatory against the rural backdrop in Mexico. Being maize the main crop in Mexico and Jalisco the largest producer of rain fed maize in the country the project "Organic farming promotion and development for grain producers in the state of Jalisco" is considered a key action for achieving rural sustainability at regional and national scale.

In this first stage, research focused on describing and evaluating achieved and expected results by contrasting them with agroecology and sustainability guidelines. I considered that the more included these principles are, the more likely to it is to achieve success for sustainability related actions.

This paper made clear that positive outcomes can be expected from applying sustainability principles and that these are not limited to improving the environment, but that actual economic and social benefits are possible. Emphasizing on local communities, their ability to experiment, implement and evaluate innovations in agricultural production systems increases the width of positive outcomes from public investment in agriculture. Crop management technologies and methods that can be locally applied while promoting natural diversity and social integration, underline that if searching to generate more opportunities for rural population, any action in this area should take into account the development of social capital and the principles of agroecology. The importance of this fact is highlighted in the current scenario that prevails in the country where the complex social, economic and political problems that have occurred (especially) over the past 15 years, have equally damaged the social fabric, the function of public institutions and the environment.

Research as well as the project, were limited by time and economic resources so carrying chemical soil analysis was not possible. The latter impeded getting tangible data on how actions made really impacted the soil composition and biological activities. If future research allows this, it will enable to deepen the analysis and to assess its effects even at early stages.

Some setbacks were also identified. The immediacy of agricultural seasons and cropping stages including natural conditions prevents farmers from waiting public administration deadlines and periods. This means that farmers cannot wait for programs to be accepted and resources to be liberated to continue their activities and much needed technical advice arrives late, having to adapt original actions to what farmers already made. This was identified as the main reason why farmers did not leave their transition cropland area totally free from chemical inputs. Also, mistrust between farmers and public administration, but even among themselves is an important obstacle to overcome though some progress was achieved by working in groups and through participative approaches.

Further research is needed in order to assess how the project actually impacts the compound between local society and the environment. This can be done through implementing and evaluating three fundamental aspects: a tool of analysis composed of theoretical principles and integrated assessment of sustainability; how the implementation of this tool 
contributes to strengthening the operational capacity of the sustainable approach and if enhances decision-making; and finally the extent to which the project achieved its objectives in terms of grounding sustainability and locally strengthening natural and social capital.

\section{ACKNOWLEDGMENTS}

The present article is part of a Ph.D. research that is made thanks to the support of the Consejo Nacional de Ciencia y Tecnología (CONACYT), Mexico. Special thanks to the UNESCO Chair in Sustainability and the Departament d'Enginyeria Tèxtil i Paperera (UPC) for structural and bibliographic resources. Thanks also to Beatriz Escribano Rodríguez de Robles for her guidance and Carlos Welsh Rodríguez for his insights.

\section{REFERENCES}

[1] WCDE, Our Common Future, Oxford University Press, 1987.

[2] Benessia, A., Funtowicz, S., Bradshaw, G., Ferri, F., Ráez-Luna, E.F. \& Medina, C.P., Hybridizing sustainability: towards a new praxis for the present human predicament. Sustainability Science, 7(1), pp. 75-89, 2012. http://dx.doi.org/10.1007/s11625-011-0150-4

[3] CEPAL-ESALC, Evaluación de la Sostenibilidad en América Latina y el Caribe, 2004.

[4] Lang, D.J., Wiek, A., Bergmann, M., Stauffacher, M., Martens, P., Moll, P., Swilling, M. \& Thomas, C.J., Transdisciplinary research in sustainability science: Practice, principles, and challenges. Sustainability Science, 7(1), pp. 25-43, 2012. http://dx.doi.org/10.1007/s11625-011-0149-x

[5] Ekins, P., Dresner, S. \& Dahlström, K., The four-capital method of sustainable development evaluation. European Environment, 18(2), pp. 63-80, 2008. http://dx.doi.org/10.1002/eet.471

[6] Hak, T., Kovanda, J. \& Weinzettel, J., A method to assess the relevance of sustainability indicators: application to the indicator set of the czech republic's sustainable development strategy. Ecological Indicator, 17, pp. 46-57, 2012. http://dx.doi.org/10.1016/j.ecolind.2011.04.034

[7] Aguilar-Jiménez, C.E., Tolón-Becerra, A. \& Lastra-Bravo, X., Evaluación integrada de la sostenibilidad ambiental, económica y social del cultivo de maíz en Chiapas, México. Rev. la Fac. Ciencias Agrar., 43(1), pp. 155-174, 2011.

[8] Astier, M., Speelman, E.N., López-Ridaura, S., Masera, O.R. \& Gonzalez-Esquivel, C.E., Sustainability indicators, alternative strategies and trade-offs in peasant agroecosystems: analysing 15 case studies from Latin America. International Journal of Agricultural Sustainability, 9(3), pp. 409-422, 2011. http://dx.doi.org/10.1080/14735903.2011.583481

[9] Koohafkan, P., Altieri, M.A. \& Gimenez, E.H., Green Agriculture: foundations for biodiverse, resilient and productive agricultural systems. International Journal of Agricultural Sustainability, 10(1), pp. 61-75, 2012. http://dx.doi.org/10.1080/14735903.2011.610206

[10] Huerta, E., Kampichler, C., Ochoa-Gaona, S., De Jong, B., Hernandez-Daumas, S. \& Geissen, V., A multi-criteria index for ecological evaluation of tropical agriculture in southeastern Mexico. PLoS One, 9(11), p. e112493, 2014.

[11] Ding, G.C., Piceno, Y.M., Heuer, H., Weinert, N., Dohrmann, A.B., Carrillo, A., Andersen, G.L., Castellanos, T., Tebbe, C.C. \& Smalla, K., Changes of soil bacterial diversity 
as a consequence of agricultural land use in a semi-arid ecosystem, PLoS One, 8(3), p. e59497, 2013.

[12] Castañeda Zavala, Y., González Merino, A., Chauvet Sánchez, M. \& Ávila Castañeda, J.F., Industria semillera de maíz en Jalisco. Actores sociales en conflicto. Sociológica, 29(83), pp. 241-278, 2014.

[13] Altieri, M.A. \& Toledo, V.M., The agroecological revolution in Latin America: rescuing nature, ensuring food sovereignty and empowering peasants. The Journal of Peasant Studies, 38(3), pp. 587-612, 2011. http://dx.doi.org/10.1080/03066150.2011.582947

[14] FAO, FAO Statistical Yearbook - Latin America and the Caribbean. Food and agriculture, Santiago de Chile, 2014.

[15] CEDRSSA, Consumo, distribución y producción de alimentos: el caso del complejo maíz-tortilla, Ciudad de México, 2014.

[16] FAO, FAOSTAT, Food and Agriculture Organization of the United Nations, 2015, available at: http://faostat3.fao.org/home/E

[17] Carro-Ripalda, S. \& Astier, M., Silenced voices, vital arguments: smallholder farmers in the Mexican GM maize controversy. Agriculture And Human Values, 31(4), pp. 655-663, 2014. http://dx.doi.org/10.1007/s10460-014-9533-3

[18] Arnés, E., Antonio, J., del Val, E. \& Astier, M., Sustainability and climate variability in low-input peasant maize systems in the central Mexican highlands. Agriculture, Ecosystems \& Environment, 181, pp. 195-205, 2013.

http://dx.doi.org/10.1016/j.agee.2013.09.022

[19] CONABIO, Comisión Nacional para el Conocimiento y Uso de la Biodiversidad (CONABIO), 2015, available at: http://www.biodiversidad.gob.mx/. (accessed 18 Febuary 2015).

[20] Bender, S.F. \& van der Heijden, M.G.A., Soil biota enhance agricultural sustainability by improving crop yield, nutrient uptake and reducing nitrogen leaching losses. Journal of Applied Ecology, 52(1), pp. 228-239, 2015. http://dx.doi.org/10.1111/1365-2664.12351

[21] Verhulst, N., Kienle, F., Sayre, K.D., Deckers, J., Raes, D., Limon-Ortega, A., Tijerina-Chavez, L. \& Govaerts, B., Soil quality as affected by tillage-residue management in a wheat-maize irrigated bed planting system. Plant Soil, 340(1-2), pp. 453-466, 2010.

[22] Altieri, M.A. \& Nicholls, C.I., Agroecological diversification strategies to enhance biological pest regulation in horticultural systems. Acta Horticulturae, 933, pp. 35-42, 2012. http://dx.doi.org/10.17660/ActaHortic.2012.933.2

[23] Calleros-Islas, A. \& Welsh-Rodriguez, C., Sustainability in practice: integrated assessment to support policy and decision-making processes. In Ecosystems and Sustainable Development X, U. J.L. Miralles i Garcia, Universitat Politecnica de Valencia, Spain and C.A. Brebbia, Wessex Institute of Technology, WIT Press: Valencia, Spain, p. 122, 015. http://dx.doi.org/10.2495/eco150351

[24] Andersen, M., ¿Es la certificación algo para mí? - Una guía práctica sobre por qué, cómo y con quién certificar productos agrícolas para la exportación / RUTA-FAO. San José; C.R.: FAO.- Series de Publicaciones RUTA: Material de Capacitación, 2003.

[25] Willer, H. \& Lernoud, J., The World of Organic Agriculture. Statistics and Emerging Trends 2014. FiBL-IFOAM REPORT, Bonn, 2014. 
[26] Willer, H. \& Lernoud, J., The World of Organic Agriculture. Statistics and Emerging Trends 2015. FIBL-IFOAM REPORT, Bonn, 2015.

[27] Organic Trade Association, Go to market report, Mexico, 2015.

[28] Valdez, J., Sánchez, I., García, C. \& Avendaño, J.C., Por alza del dólar, precios de insumos agrícolas han aumentado hasta 50\%. La Jornada, México, 2015.

[29] Govaerts, B., Sayre, K.D., Goudeseune, B., De Corte, P., Lichter, K., Dendooven, L. \& Deckers, J., Conservation agriculture as a sustainable option for the central Mexican highlands. Soil and Tillage Research, 103(2), pp. 222-230, 2009.

http://dx.doi.org/10.1016/j.still.2008.05.018

[30] Campo Orgánico Empresarial, Project files.

[31] Rosenthal, E., Organic agriculture may be outgrowing its ideals. The New York Times, New York, NY, 2011.

[32] Reed, M.S., Stakeholder participation for environmental management: A literature review. Biological Conservation, 141(10), pp. 2417-2431, 2008.

http://dx.doi.org/10.1016/j.biocon.2008.07.014

[33] Rogé, P., Friedman, A.R., Astier, M. \& Altieri, M.A., Farmer strategies for dealing with climatic variability: a case study from the mixteca alta region of Oaxaca, Mexico. Agroecology and Sustainable Food Systems, 38(7), pp. 786-811, 2014.

http://dx.doi.org/10.1080/21683565.2014.900842

[34] Holt-Giménez, E. \& Altieri, M.A., Agroecology, food sovereignty and the new green revolution. Agroecology and Sustainable Food Systems, 37(1), pp. 90-102, 2012. http://dx.doi.org/10.1080/10440046.2012.716388

[35] Merlín-Uribe, Y., González-Esquivel, C.E., Contreras-Hernández, A., Zambrano, L., Moreno-Casasola, P. \& Astier, M., Environmental and socio-economic sustainability of chinampas (raised beds) in Xochimilco, Mexico City. International Journal of Agriculture Sustainability, 11(3), pp. 216-233, 2013. http://dx.doi.org/10.1080/14735903.2012.726128

[36] SAGARPA, Secretaría de Agricultura, Ganadería, Desarrollo Rural, Pesca y Alimentación, 2015, available at: http://www.sagarpa.gob.mx/. (accessed 10 July 2015).

[37] Altieri, M.A. \& Nicholls, C.I., The adaptation and mitigation potential of traditional agriculture in a changing climate. Climatic Change, pp. 1-13, 2013. http://dx.doi.org/10.1007/s10584-013-0909-y

[38] SEDER, Secretaría de Desarrollo Rural del Estado de Jalisco, 2015, available at: http:// seder.jalisco.gob.mx/. (accessed 10 July 2015).

[39] Ichikawa, H., Neurotoxicology of pesticides. Brain and Nerve, 67(1), pp. 39-48, 2015.

[40] Fuentes, M., Hidalgo, C., Etchevers, J., De León, F., Guerrero, A., Dendooven, L., Verhulst, N. \& Govaerts, B., Conservation agriculture, increased organic carbon in the top-soil macro-aggregates and reduced soil CO2 emissions. Plant Soil, 355(1-2), pp. 183-197, 2011. 